\title{
O NOVO TITULAR, PROFESSOR VICENTE GRECO FILHO, PROFERE SEU DISCURSO DE POSSE
}

- Sonhos e responsabilidades.

São as idéias que me assaltam neste momento, acentuadas pelas gentis palavras do Professor Tercio Sampaio Ferraz Júnior, ditadas, sei bem, pela empolgante aventura de crescer, de tornar-se alguém, que tivemos a felicidade, em alguns pontos comuns e muito significantes, de conviver.

Sonhos porque, já nos bancos acadêmicos, a admiração pela instituição que nos abriga e seus mestres, inoculou o anseio de aqui chegar como professor.

Sonhos que me fazem lembrar de meus professores e preceptores, todos eles, com suas qualidades e seus defeitos, como pretendo ser assim lembrado, como pessoa, com qualidades e defeitos. Assim, não posso deixar de nominar especialmente, os Professores Moacyr Amaral Santos, meu orientador no doutorado, Alfredo Buzaid, em cuja biblioteca toda a literatura existente tive à minha disposição, Joaquim Canuto Mendes de Almeida, a inteligência brilhante que, por tradição oral, transmitiu conceitos inestimáveis, e Manoel Pedro Pimentel e Edgard de Magalhães Noronha, que me ligaram inexoravelmente ao direito penal.

Não posso deixar de homenagear, também, o antecessor no cargo que passo a ocupar, o Professor Paulo José da Costa Jr., e meus colegas titulares do Departamento, os Professores Miguel Reale Júnior e Ivette Senise Ferreira.

Todavia, pesa-me, com predominância, o sentimento de responsabilidade.

Responsabilidade perante esta Escola, perante seus alunos e perante a sociedade.

Perante a Faculdade porque é preocupante a manutenção de sua posição enquanto modelo da formação jurídica e humanística.

Perante os alunos, porque a eles, afinal, se destina tudo isto, evitandose a perigosa deformação, que já vislumbro no Brasil da universidade que vive para si mesma e não para os estudantes. 
Mas especialmente perante a sociedade, porque nós, os privilegiados que aqui tivemos a oportunidade de estudar e de conviver com os destacados colegas e mestres, muito devemos à sociedade como um todo, já que nada mais somos do que produto de seus esforços e de seus sacrifícios.

As preocupações, contudo, não serão inibitórias. Servirão para alimentar novos sonhos e, de minha parte, o estudo e o ensino jurídico encontrarão sempre a palavra: presente! 